\title{
Is stored expressed breast milk an alternative for working Egyptian mothers?
}

\author{
Z.M. Ezz El Din' ${ }^{1}$ S. Abd El Ghaffar, ${ }^{1}$ E.K. El Gabry, ${ }^{2}$ W.A. Fahmi ${ }^{3}$ and R.F. Bedair'
}

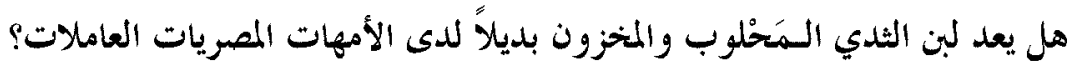

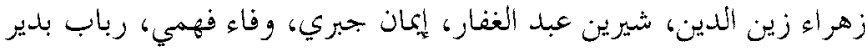

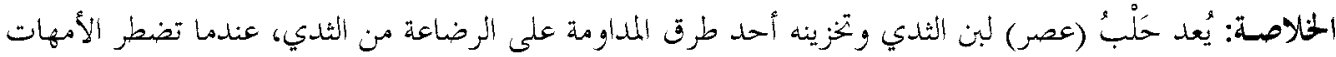

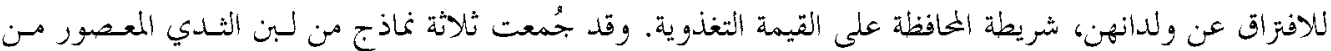

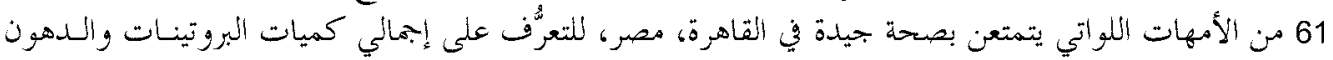

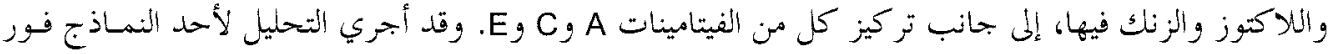

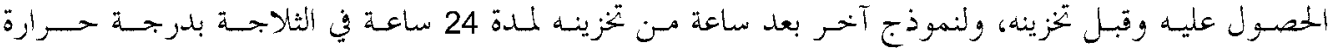

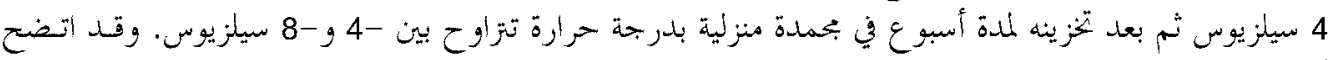

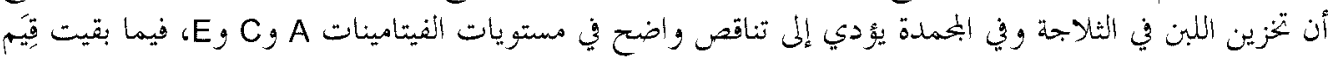

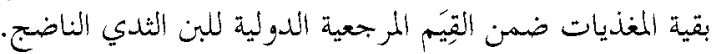

ABSTRACT Expression and storage of breast milk is way to maintain breastfeeding when mother and infant are separated, if the nutritional value can be conserved. Three expressed breast milk samples were collected from 61 healthy lactating mothers in Cairo, Egypt, for determination of total protein, fat, lactose and zinc content, as well as vitamins $C, A$ and $E$ concentrations. One sample was analysed immediately without storage, 1 after storage for 24 hours in a refrigerator $\left(4^{\circ} \mathrm{C}\right)$ and 1 after storage for 1 week in a home freezer $\left(-4^{\circ} \mathrm{C}\right.$ to $\left.-8^{\circ} \mathrm{C}\right)$. Refrigeration and freezing of breast milk caused a statistically significant decline in levels of vitamins $\mathrm{C}, \mathrm{A}$ and $\mathrm{E}$. Nevertheless, the values of all nutrients were still within the international reference ranges for mature breast milk.

\begin{abstract}
Le lait maternel extrait et conservé constitue-t-il une alternative pour la mère égyptienne qui travaille?

RÉSUMÉ L'extraction et la conservation du lait maternel constituent une manière de poursuivre l'allaitement au sein lorsque la mère et l'enfant sont séparés, si la valeur nutritive peut être préservée. Trois échantillons de lait maternel extrait ont été recueillis chez 61 mères allaitantes en bonne santé au Caire (Égypte) pour déterminer la teneur en protéines totales, en graisses, en lactose et en zinc ainsi que les concentrations en vitamines $A, C$ et $E$. Un échantillon a été analysé immédiatement sans conservation, un autre a été analysé après conservation pendant 24 heures au réfrigérateur $\left(4^{\circ} \mathrm{C}\right)$ et un troisième après conservation pendant une semaine dans un congélateur familial $\left(-4^{\circ} \mathrm{C}\right.$ à $\left.-8^{\circ} \mathrm{C}\right)$. La réfrigération et la congélation du lait maternel ont entraîné une réduction statistiquement significative de la concentration en vitamine $A, C$ et $E$. Toutefois, les valeurs de tous les nutriments étaient toujours comprises dans la fourchette de référence internationale pour le lait maternel mûr.
\end{abstract}

${ }^{1}$ Department of Paediatrics, Faculty of Medicine, University of Cairo, Cairo, Egypt.

${ }^{2}$ Department of Biochemistry, Department of Clinical Nutrition; ${ }^{3}$ Department of Nutritional Requirement and Growth, National Nutrition Institute, Cairo, Egypt.

البحلة الصحية لشرق المتو سط، منظمة الصحة العالمية، البخلد العاشر، العدد ج، ع • +. 


\section{Introduction}

Researchers, especially in recent years, have documented diverse and compelling advantages to infants, mothers, families and society from breastfeeding. They established that human milk is uniquely superior for infant feeding and is species specific, in addition to its unique immunological, growth and developmental benefits. They also suggested that benefits attributable to breastfeeding may persist past infancy [1].

When it is not possible to breastfeed an infant in the postnatal period, expressed breast milk, fresh or frozen, may provide both nutritional and immunological benefits, if its nutritional value can be conserved. In such a way, it can be fed to babies separated from the mother for 8 hours or more due to hospitalization or maternal employment $[2,3]$.

The aim of this study in Egypt was to investigate the effect of storage of breast milk on some of its chemical constituents: total protein, total fat, lactose, zinc and vitamins $\mathrm{C}, \mathrm{A}$ and $\mathrm{E}$ concentrations.

\section{Methods}

This study was carried out in Abu El-Reesh hospital outpatient clinics and Qasr El-Aini neonatal intensive care unit follow-up clinic at Cairo University. Sample collection took place from February to April 2003 at an average maximum outside temperature range of $25-30{ }^{\circ} \mathrm{C}$.

\section{Sample}

This study was carried out on 61 healthy lactating mothers who had delivered by vaginal delivery or caesarean section. Their ages ranged between 17 and 40 years, their parity between 1 and 9 and their babies' ages between 2 weeks and 1 year. All mothers were of low or intermediate socioeconomic groups. Exclusion criteria included the presence of any significant maternal disease, malnutrition or the use of any medication during lactation. Informed consent was taken from all mothers participating in the study.

\section{Sample collection and transportation}

Each mother was instructed to wash her hands carefully with soap and water before collecting the milk sample and to express some of her breast milk manually or by bicycle horn pump into 3 labelled sterile hard plastic containers (10 $\mathrm{mL}$ in each). The 3 containers were tightly closed immediately after expression. The samples were transported in an ice chest to the laboratory within 20-25 minutes.

One sample was analysed immediately as the baseline control. The second sample was stored in the first shelf of the refrigerator at $4-6{ }^{\circ} \mathrm{C}$ for 24 hours before analysis, and the third sample was stored in the freezer at -4 to $-8{ }^{\circ} \mathrm{C}$ for 1 week before analysis.

\section{Biochemical methods of milk analysis}

Milk lactose level was determined using phenol reagent and sulfuric acid [4,5]. Determination of lipids was performed by acid hydrolysis, while proteins were determined as nitrogen content of the milk sample, then multiplied by a specific factor to obtain the protein content $[4,5]$.

Determination of zinc (trace element) in milk was done by the atomic absorption spectrophotometer technique [4,5]. Determination of fat-soluble vitamins $\mathrm{A}$ and $\mathrm{E}$ was performed by high performance liquid chromatographic separation $[4,5]$. 


\section{Data analysis}

SPSS, version 9.0, was used to perform the statistical analysis. The values of breast milk nutrients at baseline were compared with reference values [6] using Student $t$ test. Paired $t$-test was used to compare between the means of baseline milk composition and after 24 hours of milk storage in the first shelf of the refrigerator, and between the means of baseline milk composition and after 1 week of freezing. $P$ values $\leq 0.05$ were regarded as statistically significant.

\section{Results}

Table 1 shows the baseline values of breast milk nutrients compared with the range of international reference values. The mean values of macronutrients, vitamins and zinc studied in the women's breast milk samples, as well as the minimum and maximum values for the group, were within the international reference range.
Table 2 shows the effect of storage of breast milk samples for 24 hours in the refrigerator $\left(4-6{ }^{\circ} \mathrm{C}\right)$, where vitamins $\mathrm{C}$ and A showed a statistically significant decrease $(P<0.05)$. Table 2 also shows the effect of storage for 1 week in the freezer $\left(-4\right.$ to $-8{ }^{\circ} \mathrm{C}$ ), where vitamins $\mathrm{C}, \mathrm{A}$ and $\mathrm{E}$ showed a statistically significant decrease $(P<0.05)$. Small reductions in the fat, protein and lactose content of breast milk were measured after refrigeration for 24 hours as well as after freezing for 1 week but these were not statistically significant. All values after storage were still within the international reference ranges [6].

\section{Discussion}

In this study, baseline measurements showed that the mean fat, protein and lactose content and the mean vitamin $\mathrm{C}, \mathrm{A}$ and $\mathrm{E}$ and zinc concentrations in expressed breast milk, as well as the overall ranges, were within the international reference

\begin{tabular}{|c|c|c|c|}
\hline \multirow[t]{2}{*}{ Nutrients } & \multicolumn{2}{|c|}{ Baseline } & \multirow{2}{*}{$\begin{array}{r}\text { Reference } \\
\text { range [6] }\end{array}$} \\
\hline & Mean (SD) & Range & \\
\hline \multicolumn{4}{|c|}{ Macronutrients ( $g / L)$} \\
\hline Fat & 35.98 (3.97) & $30-49$ & $13.4-82.9$ \\
\hline Protein & $10.55(0.63)$ & $9.6-12$ & 7.3-20 \\
\hline Lactose & $57.59(7.29)$ & $46-75$ & 49-95 \\
\hline \multicolumn{4}{|c|}{ Vitamins (mg/L) } \\
\hline Vitamin C & $47.30(9.64)$ & $32-72$ & $0-112$ \\
\hline Vitamin A & $0.27(0.00)$ & $0.2-0.46$ & $0.15-2.26$ \\
\hline Vitamin E & $1.39(0.10)$ & $1.23-1.53$ & $1.0-4.8$ \\
\hline \multicolumn{4}{|c|}{ Trace elements (mg/L) } \\
\hline Zinc & $1.145(0.145)$ & $0.8-1.4$ & $0.17-3.02$ \\
\hline
\end{tabular}

$S D=$ standard deviation.

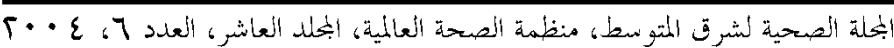




\begin{tabular}{|c|c|c|c|c|c|}
\hline \multirow[t]{2}{*}{ Nutrients } & \multirow{2}{*}{$\begin{array}{l}\text { Baseline } \\
\text { Mean (SD) }\end{array}$} & \multicolumn{2}{|c|}{$\begin{array}{c}\text { Refrigerator storage } \\
\text { (24 hours) }\end{array}$} & \multicolumn{2}{|c|}{$\begin{array}{c}\text { Freezer storage } \\
(1 \text { week })\end{array}$} \\
\hline & & Mean (SD) $d e$ & $\begin{array}{c}\% \\
\text { lecrease }\end{array}$ & $\operatorname{Mean}(S D)$ & $\begin{array}{c}\% \\
\text { decrease }\end{array}$ \\
\hline \multicolumn{6}{|c|}{ Macronutrients ( $g / L)$} \\
\hline Fat & 35.98 (3.97) & 35.84 (3.97) & 0.4 & $35.55(4.04)$ & 1.2 \\
\hline Protein & $10.55(0.63)$ & $10.12(0.82)$ & 4.1 & $9.4(0.80)$ & 10.9 \\
\hline Lactose & $57.59(7.29)$ & $57.55(7.28)$ & 0.1 & $57.30(7.43)$ & 0.5 \\
\hline \multicolumn{6}{|c|}{ Vitamins (mg/L) } \\
\hline Vitamin C & $47.30(9.64)$ & $30.24(13.74)$ & $36.1^{*}$ & 20.39 (10.99) & $56.9^{*}$ \\
\hline Vitamin A & $0.27(0.00)$ & $0.20(0.00)$ & $25.9^{*}$ & $0.14(0.00)$ & $48.1^{*}$ \\
\hline Vitamin E & $1.39(0.10)$ & $1.30(0.11)$ & 6.5 & $0.99(0.00)$ & $28.8^{*}$ \\
\hline \multicolumn{6}{|c|}{ Trace elements (mg/L) } \\
\hline Zinc & $1.145(0.145)$ & $1.143(0.143)$ & 0.2 & $1.134(0.150)$ & 0.96 \\
\hline
\end{tabular}

${ }^{*} P<0.05$

$S D=$ standard deviation.

ranges for nutrient concentrations of mature breast milk [6]. The wide variation in the composition of mature breast milk (observed in the wide ranges of the international reference values as well as in our results) can be attributed to several reasons. Factors which are known to influence the concentrations of different mature breast milk constituents in predictable ways include stage of lactation, breastfeeding routine, parity, maternal age, maternal diet and other maternal characteristics, as well as regional differences and in some situations, seasons of the year [7].

In our work, mature breast milk was taken from nursing mothers, whose infant's age ranged from 15 days up to 360 days. Other studies showed that mature breast milk composition also changes during the course of lactation, although not as markedly as in the early weeks. Many important ingredients of breast milk, such as lactose, zinc, sodium and lysozyme, show a gradual decrease in concentration of about $10 \%-30 \%$ during the first year of lactation [8]. Moreover, mature breast milk may vary during the day and from the beginning to the end of a feeding session. This is most pronounced for fat and fatsoluble components, such as vitamin A, E and zinc [9]. Moreover, Wagner documented that breast milk at the start of feeding (fore milk) has a lower fat content, and as the infant continues to breastfeed over the next several minutes, the fat content increases (hind milk), which is thought to facilitate satiety in the infant [10]. He also reported that diurnal variations in breast milk exist, which reflect maternal diet and daily hormonal fluctuations. These variations can be seen in most of the constituents in breast milk, mainly fat and proteins.

The parity of the lactating mothers in our work varied from 1 to 9 , and their ages varied from 17 to 43 years. Maternal parity and maternal age could be others explanations for the wide variations in mature breast milk composition, as shown by 
many studies $[8,11]$. It was noticed that African young primiparous mothers have higher concentration of several breast milk constituents, especially fat, protein and immunoproteins, whereas older mothers of very high parity ( 9 or more) tend to produce milk with reduced quality [11].

Even if all these various influences were taken into consideration, breast milk volume and composition would still vary considerably from one mother to another in the same population. Generally, betweenmother differences in milk volume and composition are maintained throughout lactation and are usually not related to each other $[8,11]$.

Our study revealed a small, statistically non-significant decline in the fat content of breast milk after refrigeration at $4-6{ }^{\circ} \mathrm{C}$ for 24 hours as well as after freezing at -4 to $-8{ }^{\circ} \mathrm{C}$ for 1 week. This decline was by $0.4 \%$ and $1.19 \%$ respectively. Our results tend to agree with Pardou et al. [12], who observed a non-significant decrease in total lipid content after refrigeration at $4-6{ }^{\circ} \mathrm{C}$ as well as after freezing at $-20^{\circ} \mathrm{C}$ for 8 days, which could be due to lipolysis occurring during storage. They reported that this decrease did not exceed $2.0 \%-6.7 \%$ from the initial values of fat in breast milk samples, which was not very important from the nutritional point of view.

Similarly, Silprasert et al. reported that the fat content of human milk (the creamatocrit) tended to remain stable when the milk was refrigerated at $4{ }^{\circ} \mathrm{C}$ for up to 14 days [13]. Moreover, our results match with those of Friend et al., who initiated a study to evaluate the effects of freezer storage at $-25^{\circ} \mathrm{C}$ on lipid components of mature human milk [14]. They reported that quick freezing and frozen storage tended to increase lipase activity, although these increases were not significant. Similarly, the lipid content, fatty acid levels and the relative percentage of each fatty acid were not significantly different in the frozen milk samples as compared with their levels before storage.

Our study revealed a statistically nonsignificant decrease in protein content of breast milk, after refrigeration for 24 hours as well as after freezing for 1 week. This decline was by $4.1 \%$ and $10.9 \%$ respectively. Our results tend to disagree with Garza et al., who found that there was a significant effect of storage temperature $\left(4{ }^{\circ} \mathrm{C}\right)$ on the protein nitrogen concentration, especially when the duration of storage was prolonged for 48 hours [15]. The difference in the results could be attributed to their longer duration of storage.

Moreover, this study revealed a very small, non-significant decline in lactose content of breast milk after refrigeration for 24 hours or after 1 week of freezing (decreased by $0.07 \%$ and $0.5 \%$ respectively). Our results match with those of Pardou et al., which showed that there was no significant decline over time (up to 8 days) in lactose content of refrigerated milk samples at $0-4{ }^{\circ} \mathrm{C}$ or after freezing at $-20{ }^{\circ} \mathrm{C}$ [12]. They explained that this could be related to the absence of lactose-fermenting bacteria in the carefully collected breast milk samples.

In our study, there was a statistically significant decline in the studied vitamins (C and $\mathrm{A}$ ) in breast milk after refrigeration for 24 hours and in vitamins C, A and E after freezing for 1 week. This decline was $36 \%$ and $56.9 \%$ respectively for vitamin C, $25.9 \%$ and $48.1 \%$ for vitamin A and $28.8 \%$ for vitamin $\mathrm{E}$ (after freezing). Our results regarding vitamin $\mathrm{C}$ are in agreement with Garza et al. [15]. In their study, human milk samples were stored at $4{ }^{\circ} \mathrm{C}$ and were analysed after 4, 24 and 48 hours storage. The researchers discovered a significant effect of storage duration and temperature

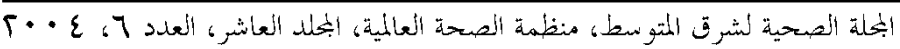


on vitamin $\mathrm{C}$ concentrations. They reported that refrigeration at $4{ }^{\circ} \mathrm{C}$ resulted in a significant decline in vitamin $\mathrm{C}$ content in milk and that this decline was exaggerated with prolonged duration. However, they revealed that milk refrigeration at $4{ }^{\circ} \mathrm{C}$ for 24 hours maintained vitamin $\mathrm{C}$ levels at $60 \%$ of values observed before refrigeration. Moreover, our results also agree with Buss et al., who found that after 24 hours refrigeration at $4-6{ }^{\circ} \mathrm{C}$, mean vitamin $\mathrm{C}$ concentration decreased to $65 \%$ of the pre-storage values [16]. However, the range of vitamin C losses varied widely, from $6 \%-76 \%$. They reported that initially $91 \%$ of total vitamin $\mathrm{C}$ was in the ascorbic acid form. After storage the proportion of ascorbic acid decreased, but this also varied widely for different milk samples. Buss et al. have also studied the effect of storage of expressed breast milk for 1 week, 1 month and 2 months in a freezer $\left(-16^{\circ} \mathrm{C}\right)$ on total vitamin $\mathrm{C}$ concentration [16]. They found that after 1 week of freezing, total vitamin $\mathrm{C}$ concentration decreased to $92 \%$ of the initial concentration (the range of losses was $83 \%-100 \%$ ), whereas after 1 month of freezing total vitamin $\mathrm{C}$ concentration decreased to $63 \%$ (range $0 \%-97 \%$ ) and 2 months of freezing decreased it to $38 \%$ of initial concentration (range $0 \%-83 \%$ ). The authors verified that the mechanism of vitamin C loss after storage is partly due to lactoperoxidase activity. They explained that the decline in vitamin $C$ levels could be due to oxidation of ascorbic acid during storage. Therefore, based on the wide and unpredictable variations in vitamin $\mathrm{C}$ losses in stored breast milk samples, it was recommended that the storage duration should be as short as possible and if long-term stored milk was to be given, vitamin $\mathrm{C}$ supplementation should be considered [16].

As for the other vitamins measured, our results tend to disagree with Garza et al. who reported that there was no significant change in vitamin A concentration of breast milk after 4 and 24 hours of refrigeration at $4{ }^{\circ} \mathrm{C}$ [15]. Our results match better with those of Moffat et al., who reported a nonsignificant effect of storage of pooled human milk on vitamin $\mathrm{E}$ concentrations (mainly $\alpha$-and $\gamma$-tocopherols) when pooled milk samples were stored for 24 hours at $4{ }^{\circ} \mathrm{C}[17]$.

Our study revealed a non-significant change in zinc content in expressed breast milk after refrigeration for 24 hours or after freezing for 1 week. Similarly Garza et al. determined the effect of storage of breast milk on its zinc content [15]. Milk samples were stored in a refrigerator at $4{ }^{\circ} \mathrm{C}$ or stored after pasteurization and freezing for 4 hours and 24 hours, with no significant change in zinc content. However, they noticed that pasteurization followed by freezing of human milk caused a significant shift in the relative distribution of zinc in fat, whey and casein fractions, with a decrease in the whey fraction of zinc and an increase in its fat fraction. They concluded that this redistribution and alteration in zinc-binding pattern during pasteurization and freezing storage of human milk might reduce its bioavailability to the infant [15].

To conclude, our study has shown that storage of expressed breast milk caused a decline in vitamins $\mathrm{A}$ and $\mathrm{C}$ concentrations after 24 hours in a refrigerator $\left(4^{\circ} \mathrm{C}\right)$ and a decline in vitamins $\mathrm{A}, \mathrm{E}$ and $\mathrm{C}$ after 1 week in a freezer $\left(-4\right.$ to $\left.-8{ }^{\circ} \mathrm{C}\right)$. However, the mean values as well as the range of values after storage were still within the international reference ranges. Total protein, fat and lactose content as well as the zinc content of expressed breast milk were not affected by storage. Therefore, it can be concluded that it could be nutritionally safe to supply expressed human milk that has 
been stored for 24 hours in refrigerator and up to 1 week in freezer. Further studies are needed to understand the effect of different temperatures and durations of storage on different constituents of expressed breast milk.

\section{References}

1. Fulhan J, Collier S, Duggan C. Update on pediatric nutrition: breastfeeding, infant nutrition, and growth. Current opinion in pediatrics, 2003, 15:323-32.

2. Netshandama VO. Breastfeeding practices of working women. Curationis, 2002, 25:21-7.

3. Smith A. Guidelines for storing human milk. familyresource.com [online article] (http://www.familyresource.com/pregnancy/16/285/, accessed 9 February 2005).

4. Official methods of analysis, 13th ed. Washington, DC, Association of Official Analytical Chemists, 1990.

5. Kirk RS, Sawyer R, eds. Pearson's composition and analysis of foods, 9th ed. Harlow, Longman, 1991.

6. Curran SJ, Barness LA. Nutrition: the feeding of infants and children. In: Behrman RE, Kliegman RM, Jenson HB, eds. Nelson textbook of pediatrics. Philadelphia, WB Saunders, 2000:149-69.

7. Prentice A. Regional variations in the composition of human milk. In: Jensen RG, ed. Handbook of milk composition. New York, Academic Press, 1995:115221.

8. Michaelsen KF et al. The Copenhagen cohort study on infant nutrition and growth: breast-milk intake, human milk macronutrient content, and influencing factors. American journal of clinical nutrition, 1994, 59:600-11.

9. Jensen RG. Lipids in human milk composition and fat soluble vitamins. In: Lebenthal E, ed. Textbook of gastroenterology and nutrition in infancy. New York, Raven Press, 1989:157-208.
10. Wagner CL. Human milk and lactation. eMedicine [online journal] (http:// w w w. e m edicine.com/ped/ topic2594.htm, accessed 9 February 2005).

11. Dewit O, Dibba B, Prentice A. Breast-milk amylase activity in English and Gambian mothers: effects of prolonged lactation, maternal parity, and individual variations. Pediatric research, 1990, 28:5026.

12. Pardou $A$ et al. Human milk banking: influence of storage processes and of bacterial contamination on some milk constituents. Biology of the neonate, 1994, 65:302-9.

13. Silprasert A et al. Effect of storage on creamatocrit and total energy content of human milk. Human nutrition. Clinical nutrition, 1987, 41:31-6.

14. Friend BA et al. The effect of processing and storage on key enzymes, B vitamins and lipids of mature breast milk. I. Evaluation of fresh samples and effects of freezing and frozen storage. Pediatric research, 1983, 17:61-4.

15. Garza C et al. Effects of methods of collection and storage on nutrients in human milk. Early human development, 1982, 6:295-303.

16. Buss IH et al. Vitamin $\mathrm{C}$ is reduced in human milk after storage. Acta paediatrica, 2001, 90:813-5.

17. Moffatt PA et al. Alpha and gamma tocopherols in pooled mature human milk after storage. Journal of pediatric gastroenterology and nutrition, 1987, 6:225-7.

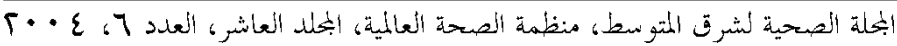

